\title{
THE MUSEUMS ASSOCIATION
}

T HE sixty-sixth annual conference of the Museums Association was held in the city of Stoke.onTrent during July 4-8, by kind invitation of the Corporation and University College of North Staffordshire. Dr. W. E. Swinton, of the British Museum (Natural History), presided over some 330 delegates.

The conference was warmly welcomed at this its first visit to Stoke by the Lord Mayor, and in his presidential address Dr. Swinton dwelt on the present plight and difficulties of the museum movement. He welcomed increased grants made by the Treasury to the national museums, and the provincial museums through the scheme administered by the Victoria and Albert Museum. He also looked forward to the founding of further regional councils based on the existing prototype in the south-west of England. Dr. Swinton deplored the absence of travelling museums in rural districts, for they had been so eminently successful in the United States, and he folt convinced that they would supply a real need in Britain. Dr. Swinton, taking his text from the underground geology in the area, then discussed the injection of art and science into industry and the way in which literature and the arts had influenced the industrial life of the city.

The presidential address thus paved the way for the main discussion of the conference, which concerned itself with the relations of museums and industry, introduced by Sir Colin Anderson, Mr. Ian Cox, Mr. John Moores and Sir John Wedgwood. All speakers agreed that with the competition of television and shop displays the standard of exhibition in museums should be high and modern in outlook. It was also felt that the displays should be stimulating and give pleasure as well as instruction. Curators should study the methods of salesmanship. In the same way that no shop would freeze its windows, museums must be prepared to change their displays as often as possible. Museums, on their part, can do much to stimulate new designs and help to maintain high standards of craftsmanship.

Another important discussion concerned the purchase of art objects for museums. The speakers included Sir Anthony Blunt, Dr. Trenchard Cox, and Messrs. G. L. Conran, Terence Mullaly and Hugh Scrutton. It was generally agreed that directors should make more frequent contact with the London market, although even then purchases were to $\mathbf{a}_{0}$ great extent a matter of chance with either local or national opportunities. It was also stressed that rare and expensive objects should not be the desiderata of museums but they should endeavour to create an individual character.

At the annual general meeting it was decided to increase institutional members on the Council from three to six and to request nominations for these from regional organizations.

Dr. D. B. Harden (London Museum) was elected president and $\mathrm{Mr}$. Phillip James was confirmed in his office as secretary. It was decided to hold the next conference at Plymouth during June 19-24, 1961.

Social functions included an informal reception at Keele Park by invitation of the University College, a reception and dance by invitation of the Lord Mayor and tours of the Arnold Bennett country, the Potteries, Kedleston and Dovedale. Official visits were also made to the local museums.

\section{THE BRITISH STEEL CASTINGS RESEARCH ASSOCIATION}

$\mathrm{T}$ $\mathrm{HE}$ progressive growth of one of the youngest research associations was marked recently by the open days held during June 28-30 by the British Steel Castings Research Association at its Research Station in Sheffield. The open days were attended by 546 representatives, principally from member companies and from users of steel castings.

The opening of the Association's Research Station. was noted in these columns (Nature, 180,$221 ; 1957$ ). Within three years the Association has found it necessary to add a further $10,000 \mathrm{sq}$. $\mathrm{ft}$. to its accommodation, while its staff has increased in this period from forty-nine to seventy-six. The increased accommodation has provided substantially more space in laboratories devoted to chemical analysis, metallurgy, sand testing and mechanical testing. The machine shop has been correspondingly enlarged, and new laboratories have been provided for radiography and the handling of isotopes used in investigations employing radioactive tracers and for the analysis of gases in steel. The experimental foundry has also been enlarged to the extent of 50 per cent in floor area, providing floor space for the installation of a 56-lb. vacuum melting furnace, for pilot plant studies of dust and fume collection equipment and for the study of foundry plant and equipment on a scale approximating to that of installations in production foundries. The total cost of the extensions together with the equipment installed therein has been $£ 60,000$, bringing the total cost of the Research Station to $£ 165,000$ within a period of four years. The present income of the Association is a little more than $£ 100,000$ per annum. The number of steel foundries in Great Britain is not large, and the present subscription income represents an average subscription of $\mathcal{E} 1,000$ a member. That the Association can maintain such a high level of subscription and has, in fact, recently increased the subseription rate by nearly 10 per cent is indicative of the importance that the industry attaches to its co-operative research.

The demonstrations of the Association's work, which were on show at the open days, illustrated vory well the point that many of the problems associated with the production of steel castings are non-metallurgical in character. A large proportion of the research effort is concerned with moulding materials and with the interactions that occur at high temperatures between molten steel and the sands and 